\section{Acknowledgments}

We are grateful to A.R. Kortan and K.M. Rabe for helpful discussions of quasicrystals.

\section{References}

1. Structure Reports, 8-46A (1940-1981), Reidel, Dordrecht.

2. CRYSTDAT (1987), developed jointly by Canada Inst. Sci. Tech. Inf., Canada Scient. Numer. Database Serv, and Nat. Inst. Stand. Tech., Gaithersburg, MD., with 180,000 entries; JCPDS, published by Intl. Centre for Diffraction DATA, 1601 Park Lane, Swarthmore, PA 190812389.

3. Pearson's Handbook of Crystallographic Data for Intermetallic Phases, P. Villars and L.D.
Calvert (ASM International, Materials Park, $\mathrm{OH}, 1991$ ), with 50,000 entries organized according to structure type.

4. J.G. Bednorz and K.A. Muller, Z. Phys. B64 (1986) p. 189.

5. C. Michel and B. Raveau, Chim. Min. 21 (1984) p. 407.

6. M.K. Wu et al., Phys. Rev. Lett. 58 (1987) p. 908.

7. I.D. Brown and J.C. Phillips (unpublished).

8. T. Siegrist, S.M. Sahurak, DW. Murphy, and R.S. Roth, Nature 334 (1988) p. 231.

9. T. Siegrist, J. Res. Nat. Inst. Stand. Tech. 94 (1989) p. 49

10. M. Takano, M. Azuma, Z. Hiroi, Y. Bando, and Y. Takeda, Physica C176 (1991) p. 441.

11. H. Adachi, T. Satoh, Y. Ichikawa, K. Setsune, and K. Wasa, Physica C196 (1992) p. 14.
12. W.A. Cassada, G.J. Shiflet, and S.J. Poon, Phys. Rev. Lett. 56 (1986) p. 2276.

13. W. Ohashi and F. Spaepen, Nature 230 (1987) p. 555.

14. P. Villars, J.C. Phillips, and H.S. Chen, Phys. Rev. Lett. 57 (1986) p. 3085.

15. J.C. Phillips and K.M. Rabe, Phys. Rev. Lett. 66 (1991) p. 923.

16. K.M. Rabe, J.C. Phillips, and P. Villars, J. Non-Cryst. Solids (in press).

17. J.C. Phillips, Phys. Rev. B (in press).

18. W. Liu, M. Schmücker, and U. Köster, Phys. Status Solidi 124a (1991) p. 75.

19. K.M. Rabe, J.C. Phillips, P. Villars, and I.D. Brown, Phys. Rez! B 45 (1992) p. 7650

20. J.C. Phillips, Phys. Rev. B 46 (1992) p. 8542.

\title{
New MRS Short Course on Practical Electron Diffraction
}

The Materials Research Society has announced an addition to its Short Course Program for the Spring Meeting in San Francisco, April 12-16, 1993. Ron Anderson, IBM East Fishkill, an experienced short course instructor, will teach a two-day course on Practical Electron Diffraction.

The MRS Continuing Education Committee has recognized the needs of members in industry and government laboratories who are being cross-trained in unfamiliar areas or whose formal training was many years in the past. This course will emphasize simple solutions to real electron diffraction problems utilizing a "mathematically nonthreatening" approach, with in-class problem solving.

Especially suitable for people working in materials science, ceramics, and mineralogy, this course is directed toward those who wish to enhance their TEM skills by performing routine electron diffraction on the transmission electron microscope and by identifying crystalline phases from diffraction patterns. Upon completion of the course, graduates will really know the principles underlying the routine operation of an electron microscope in various diffraction modes, how to obtain and measure electron diffraction patterns, and how to identify crystalline substances present in a variety of specimens. Prospective students will be expected to have a basic knowledge of the transmission electron microscope, acquired either through an introductory course or from experience. There is no diffraction experience prerequisite.

In addition to covering crystallography and diffraction fundamentals, and solving singlecrystal electron diffraction problems, this course will emphasize the utilization of electron diffraction databases for solving unknown phases and mixtures of phases. How to proceed when the unknown phase is not in- cluded in a database will also be explained.

Ron Anderson is senior physicist, East Fishkill Facility. Active in transmission electron microscopy for over 25 years, his research interests include analytical electron microscopy of semiconductors, electronic ceramics, and thin metal films, as well as electron diffraction and standardization of diffraction data. He chairs the JCPDS-ICDD Electron Diffraction Subcommittee and has, since 1975 , played an active role in the design and implementation of all ICDD electron diffraction products. Anderson was Editorin-Chief of the Electron Microscopy Society Bulletin and one of the founding editors of the Powder Diffraction journal.

Information about the course can be obtained by calling the Materials Research Society at (412) 367-3003. 